\title{
Mortality and pathology in brown bullheads Amieurus nebulosus associated with a spontaneous Edwardsiella ictaluri outbreak under tank culture conditions
}

\author{
Luke R. Iwanowicz ${ }^{1,2,}$, Alison R. Griffin ${ }^{1}$, Deborah D. Cartwrightt ${ }^{1,3}$, Vicki S. Blazer ${ }^{1}$ \\ ${ }^{1}$ National Fish Health Research Laboratory, US Geological Survey, 11649 Leetown Road, Kearneysville, \\ West Virginia 25430, USA \\ ${ }^{2}$ Department of Natural Resources Conservation, University of Massachusetts, Amherst, Massachusetts 01003, USA \\ ${ }^{3}$ Environmental Health Sciences, University of Georgia, Athens, Georgia 30602-2102, USA
}

\begin{abstract}
Brown bullheads Amieurus nebulosus (family Ictaluridae) are commonly used as a sentinel of environmental contamination. These fish are not generally cultured under laboratory conditions and little is known about their disease susceptibility. Here we report an outbreak of disease due to Edwardsiella ictaluri in a laboratory population of tank-reared, wild-caught brown bullheads. The isolate was positively identified as E. ictaluri using standard bacteriological substrate utilization tests and a monoclonal antibody specific for this bacterium. This pathogen causes a significant disease in channel catfish Ictalurus punctatus and is associated with disease in other ictalurid and non-ictalurid fishes. It appears that E. ictaluri is also a significant pathogen in brown bullheads and produces clinical signs and lesions similar but not identical to those observed in channel catfish. Since commercial sources of bullheads for laboratory tank studies are not available, precautions should be taken to prevent potential E. ictaluri disease outbreaks from wild-caught bullheads intended for laboratory research.
\end{abstract}

KEY WORDS: Amieurus nebulosus $\cdot$ Brown bullhead $\cdot$ Edwardsiella $\cdot$ Enteric septicemia of channel catfish $\cdot$ ESC $\cdot$ Pathology

Resale or republication not permitted without written consent of the publisher

\section{INTRODUCTION}

Edwardsiella ictaluri is the causative agent of enteric septicemia of channel catfish (ESC). This disease was first described in channel catfish Ictalurus punctatus by Hawke (1979), and the causative organism was later identified and characterized (Hawke et al. 1981). The pathogen is a gram-negative, catalase-positive, cytochrome oxidase-negative, enteric bacterium that ferments a limited number of carbohydrates in standard bacteriological media (Waltman et al. 1986). ESC outbreaks usually occur when water temperatures are between 20 and $30^{\circ} \mathrm{C}$, and the disease normally affects catfish raised under intensive aquaculture conditions (MacMillan 1985, Shotts \& Plumb 2003). Presently, ESC is one of the most economically important diseases of channel catfish in the Southeastern United
States, and it appears that this organism occurred as a pathogen in the channel catfish industry as early as the 1960s (Mitchell \& Goodwin 1999).

Edwardsiella ictaluri was originally considered to be a pathogen exclusive to ictalurids. Natural infections with this enteric pathogen have been observed in channel catfish, white catfish Ameiurus catus, black bullhead $A$. melas, yellow bullhead $A$. natalis, brown bullhead $A$. nebulosus, striped catfish Pangasius hypophthalmus (Crumlish et al. 2002, Yuasa et al. 2003) and walking catfish Clarius batrachus (Kasornchandra et al. 1987). Descriptions of E. ictaluri in most of the North American ictalurids listed above do not appear in the primary literature. Rather, they are included in the AFS Blue Book (Shotts \& Plumb 2003) in a list of susceptible species, presumably based on diagnostic case reports. Consequently, the circumstances of the isolations and rela- 
tive susceptibility of these species to E. ictaluri are not available. In addition to ictalurids, this organism has also been isolated from moribund green knifefish Eigenmannia virescens, cultured eels Anguilla japonica, the Bengal danio Danio devario and blue tilapia Tilapia aurea (Kent \& Lyons 1982, Waltman et al. 1985, Chung \& Kou 1987). Efforts to produce the disease in commonly cultured species including largemouth bass Micropterus salmoides, bighead carp Aristichthys nobilis, golden shiner Notemigonus crysoleucas, and white sturgeon Acipenser transmontanus have been unsuccessful (Plumb \& Sanchez 1983, Baxa et al. 1990).

The purpose of this communication is to document the isolation of Edwardsiella ictaluri from an outbreak of ESC in cultured brown bullheads and to describe the associated gross and histological pathology. Little is known about the significance of E. ictaluri in brown bullheads or the specific details regarding the clinical signs and associated pathogenesis of the disease it causes. During recent years the brown bullhead has been utilised as a useful sentinel species facilitating environmental health assessment (Johnston \& Baumann 1989, Hasspieler et al. 1994, Ploch et al. 1998, Arcand-Hoy \& Metcalfe 1999, 2000, Ploch et al. 1999, Henson et al. 2001). In order to use this species as a sentinel of environmental contamination laboratory studies designed to better understand the physiological responses to xenobiotic contaminants are needed, and this research requires routine tank culture of brown bullheads in laboratory settings. Given that tank culture of this species for laboratory research is likely to increase, documentation and description of disease issues are essential.

\section{MATERIALS AND METHODS}

Fish maintenance. During late September of 2004, approximately 500 brown bullheads of mixed sizes (12 to $25 \mathrm{~cm}$ total length, TL) collected from South Creek (Aurora, North Carolina, USA) were transported to the National Fish Health Research Laboratory in Kearneysville, West Virginia, USA. Fish were briefly held at $18^{\circ} \mathrm{C}$ in a warmwater flow-through system fed with well water. Within days the fish were transferred to a $\approx 2000$ l recirculating system with approximately 5 to $10 \%$ water replacement daily. Over a 2 wk period water temperature was increased from 18 to $22 \pm 1^{\circ} \mathrm{C}$.

Necropsy and sample preparation. Moribund and freshly dead brown bullheads were aseptically necropsied following euthanasia in tricaine methanesulfonate. Cultures from the liver, spleen and posterior kidney were plated onto tryptic soy agar (TSA) plates and incubated at room temperature or $30^{\circ} \mathrm{C}$. Liver, spleen, posterior kidney, trunk musculature and digestive tract samples were removed and fixed in $10 \%$ neutral buffered formalin for histological analysis. Samples for histology or bacteriology were only taken from live, moribund fish. Tissues were processed for histology, embedded in paraffin, sectioned at $6 \mu \mathrm{m}$, and stained with haematoxylin and eosin. Gram stains were performed to detect the bacteria in the affected organs.

Serological identification. Dot-blots were performed to serologically identify the bullhead isolate as Edwardsiella ictaluri. The bullhead isolate, E. ictaluri (positive control; supplied by Dr. Clifford Starliper) and Yersinia ruckeri (negative control), were grown in tryptic soy broth (TSB) for $48 \mathrm{~h}$, washed in Tris-buffered saline (TBS; $50 \mathrm{mM}$ Tris, $0.9 \%$ sodium chloride, $\mathrm{pH} 8.0$ ) and diluted to an optical density $\left(\mathrm{OD}_{600}\right)$ of 0.15 . Ten-fold serial dilutions were made in TBS, and $100 \mu \mathrm{l}$ of each dilution were added to the wells of a dot-blot apparatus (Bio-Rad) and blotted to a polyvinylidene fluoride (PVDF) membrane under vacuum. Wells were washed with TBS and the membrane was blocked with Trisbuffered saline with Tween 20 (TTBS; 50 mM Tris, $0.1 \%$ Tween-20, $0.9 \%$ sodium chloride, $\mathrm{pH} 8.0$ ) containing $3 \%$ goat serum in for $30 \mathrm{~min}$. The blot was thoroughly washed in TTBS and incubated with an E. ictalurispecific monoclonal antibody (developed by Dr. John Plumb; kindly donated by Dr. Andrew Goodwin) for $1 \mathrm{~h}$ (Earlix et al. 1996). The primary antibody (Ab) was detected with a goat anti-mouse IgG specific antibody conjugated to horseradish peroxidase (HRP; Jackson Immunological). Colour was developed using the HRP substrate, 3-amino, 9 ethyl-carbazole (AEC; CalBiochem) as per the manufacturer's suggested protocol.

Bacteriology. Individual colonies were transferred from primary TSA plates into TSB. Biochemical tube tests including cytochrome oxidase, catalase, triple sugar iron (TSI), Simmon's citrate, indole, gelatin, methyl red (MR), Vogues-Proskauer (VP), phenylalanine, lysine, arginine, ornithine were performed at 25 or $30^{\circ} \mathrm{C}$. Carbohydrate utilisation was determined using $\mathrm{O} / \mathrm{F}$ basal medium with the appropriate sugars added at a final concentration of $1 \%$. Carbohydrates tested included galactose, lactose, maltose, malonate, mannitol, mannose, rhamnose, sorbitol, sucrose, trehalose and xylose (Waltman et al. 1986).

\section{RESULTS}

\section{Clincal presentation and gross pathology}

Disease-associated mortality was observed when water temperatures reached $22 \pm 1^{\circ} \mathrm{C}$. Approximately 35 to $40 \%$ of the tank population died during the acute outbreak, and reducing the water temperature coupled with the administration of medicated feed 
(oxytetracycline; OTC) seemed to abate the disease process (Fig. 1). Affected fish were observed swimming erratically in a spiral motion along the longitudinal axis. Externally, petechial haemorrhages were observed on the ventral surface of the fish, and the vent was often swollen and reddened (Fig. 2a). Haemorrhagic lesions were observed circumscribing the pupil in the eyes. Raised, circular reddened lesions and depigmented spots measuring 1 to $3 \mathrm{~mm}$ were present on the lateral trunk during the initial weeks of the outbreak. Often these lesions occurred as shallow ulcers characteristic of the 'buckshot' lesions reported in channel catfish. Reddening inside and around the oral cavity was observed in all of the affected fish (Fig. 2c). Internally, petechial haemorrhages were observed along the oesophagus and lower intestine. Intestinal intussusception was observed in a number of fish during the acute outbreak. In many cases, red and white mottling was present in the liver, and both the spleen and trunk kidney were enlarged. Bloody ascites was only observed in a few fish. The 'hole in the head' lesion commonly associated with the chronic form of ESC was not observed during the initial acute outbreak; however, it was observed in fish that died $8 \mathrm{wk}$ following the acute outbreak (Fig. 2b). At this latter time a few fish with no external lesions were seen swimming in circles in a head-chase-tail manner due to severe scoliosis possibly from neurological damage.

\section{Histopathology}

Histologically, lesions occurred in the liver, intestine, dermis, and posterior kidney. Gill, heart and neural tissues were not examined. The most frequent lesions

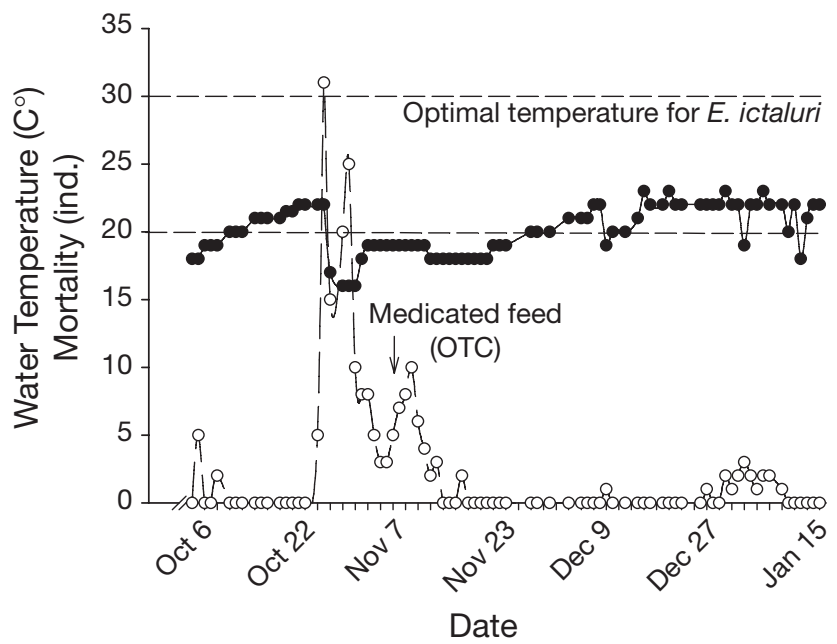

Fig. 1. Amieurus nebulosus. Edwardsiella ictaluri-associated mortality in brown bullheads $(\mathrm{O})$ and the corresponding daily temperatures (๑). OTC: oxytetracycline
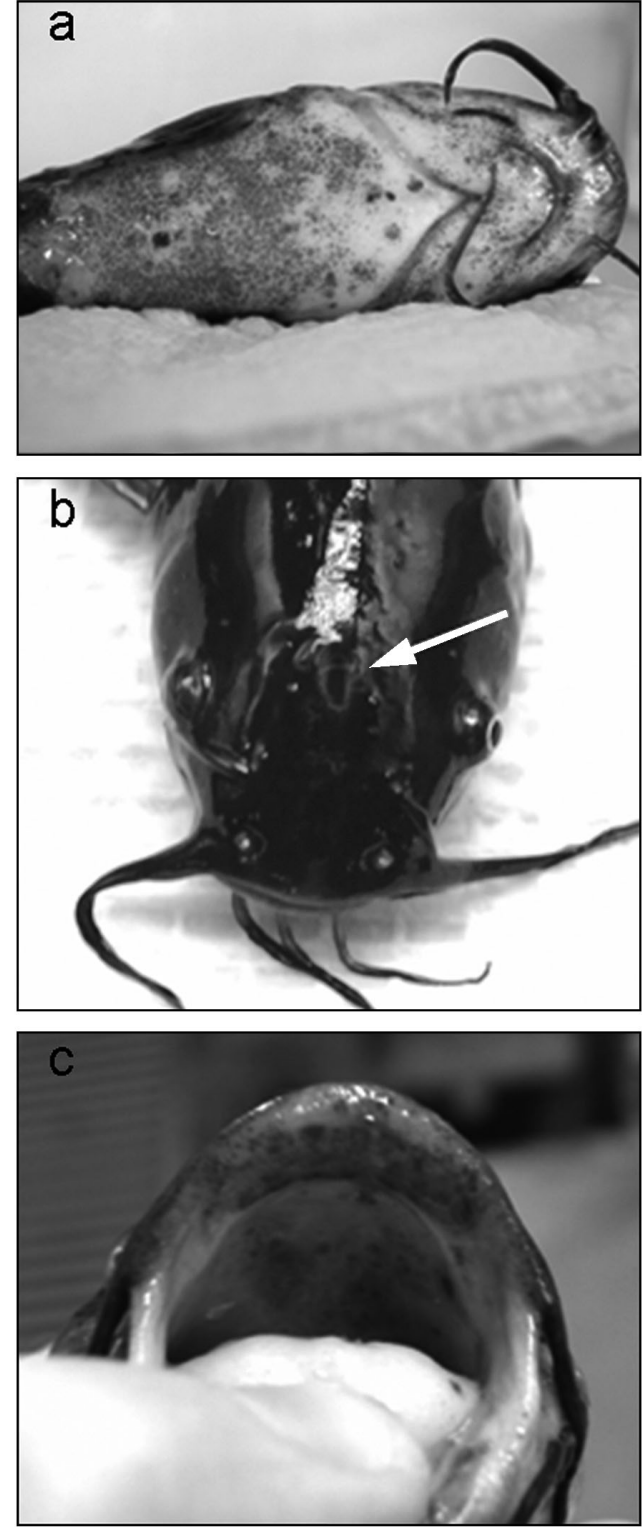

Fig. 2. Amieurus nebulosus. Gross pathology of Edwardsiella ictaluri infection in brown bullhead: (a) petechial hemorrhages on the ventral surface of an acutely infected brown bullhead; (b) hole in the head lesion (arrow) associated with the chronic form of enteric septicemia of channel catfish (ESC); (c) reddening inside and around the oral cavity

in the liver consisted of diffuse, multifocal granulomatous inflammation, hepatocyte necrosis and erythrocyte congestion (Fig. 3a). Lymphocytic infiltration was not commonly associated with the liver lesions, but when lymphocytes were present, they were observed in association with the multifocal sites of granulomatous inflammation (Fig 3b). Short, gram-negative rods were often found within phagocytic inflammatory cells or hepatocytes. Perivascular cuffing by macrophages 
and occasionally by neutrophils was evident in some fish (Fig. 4). Macrophages were commonly found extravasating from hepatic and renal vessels. Ellipsoids were apparent in the spleen due to a lack of white pulp. While this organ was relatively devoid of lymphocytes, there did not appear to be a depletion of erythrocytes.

Severe to moderate, diffuse necrosis of the haematopoietic interstitial tissue of the posterior kidney was evident in fish during the acute phase of the outbreak. Bacterial foci were associated with necrotic areas of the interstitium (Fig. 5). Renal tubular cells were often vacuolated, and degenerating tubules were common. The lumen of intact tubules often contained a fine, granular eosinophilic filtrate. The parietal epithelium of Bowman's capsule was hypertrophied, but otherwise the glomeruli were relatively unaffected. Histologically, the skin lesions exhibited haemorrhage in the dermis and disruption of the melanophores in the pigment layer

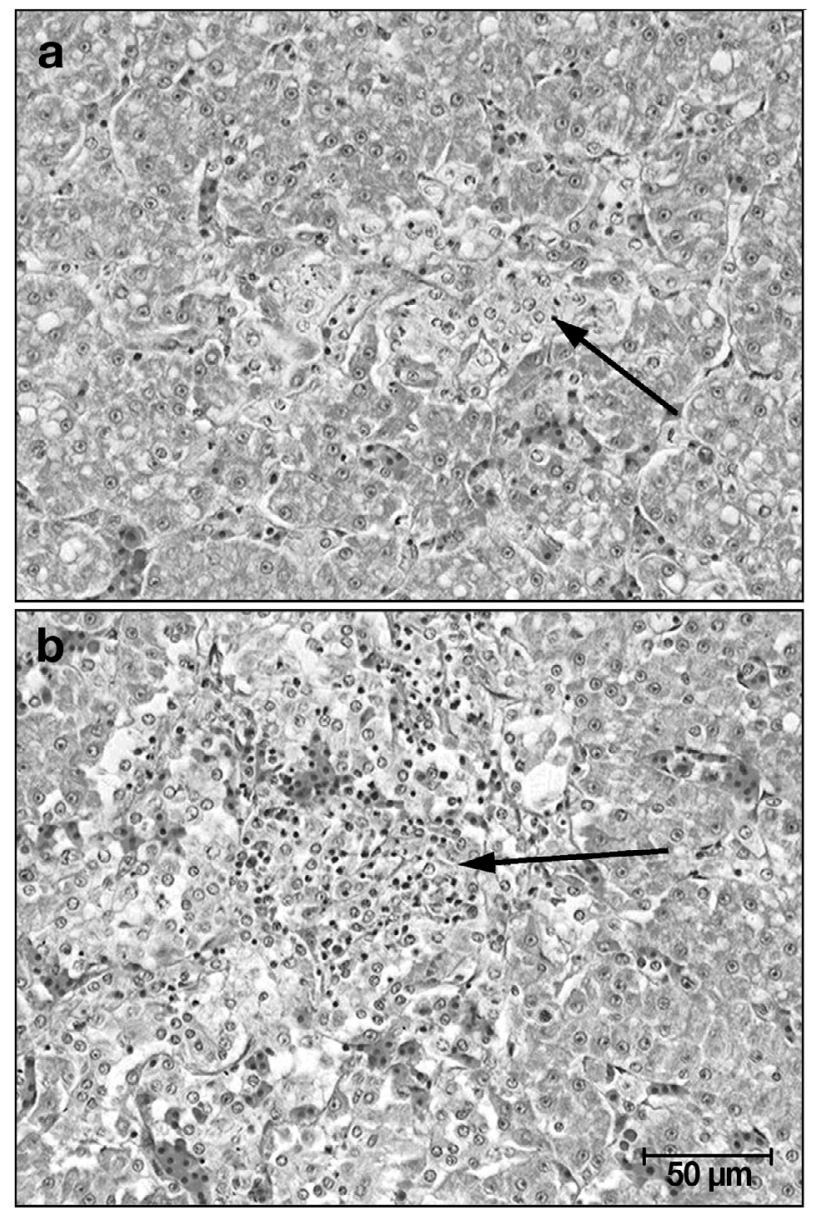

Fig. 3. Edwardsiella ictaluri in Amieurus nebulosus. Histological section of liver from an infected bullhead: (a) diffuse, multifocal granulomatous inflammation (arrow) and hepatocyte necrosis; (b) lymphocyte infiltration associated with granulomatous inflammation (arrow). H\&E staining

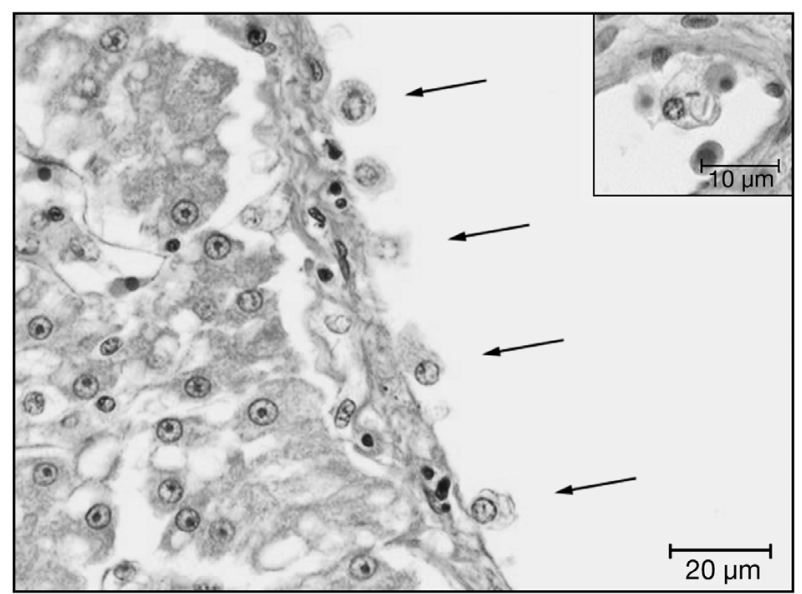

Fig. 4. Edwardsiella ictaluri in Amieurus nebulosus. Histological section of a hepatic artery from an infected bullhead with perivascular cuffing by macrophages (arrows) phagosome containing short, gram-negative rods in a circulating macrophage (inlay). H\&E staining

(Fig. 6a,c). Disruption of the pigment layer and dermal hemorrhage explained the gross 'buck shot' appearance of the skin. Occasionally, phagocytes containing bacteria were present in these lesions (Fig. 6b,c).

\section{Bacteriology and immuno dot-blot}

The biochemical characteristics of the isolate are summarized in Table 1. In general, the characteristics were consistent with those described for Edwardsiella ictaluri with the exception of the methyl red reaction. Results from this test were negative upon multiple repetitions.

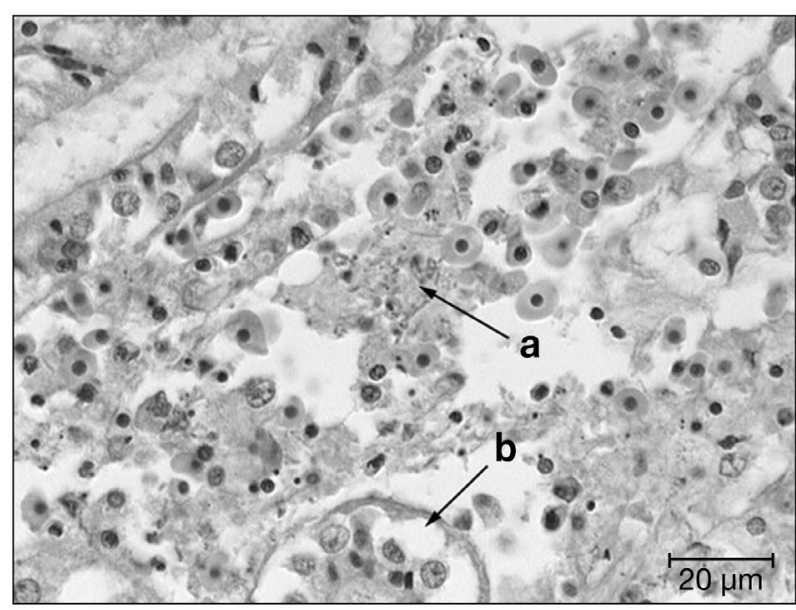

Fig. 5. Edwardsiella ictaluri in Amieurus nebulosus. Histological section of an infected posterior kidney. Focal area of bacteria in a necrotic focus in the interstitial space of the posterior kidney (arrow a). Vacuolation of renal tubular cells (arrow b). H\&E staining 

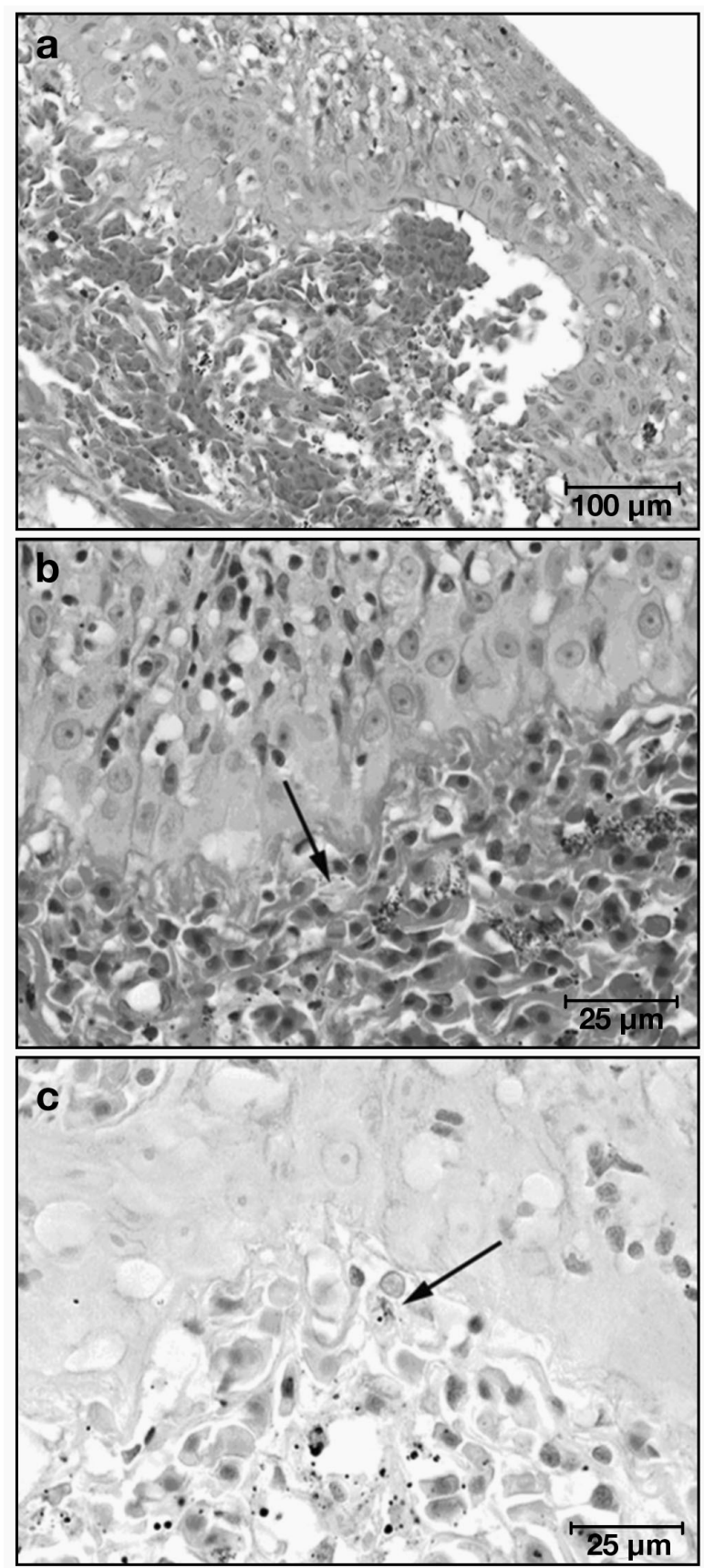

Fig. 6. Edwardsiella ictaluri in Amieurus nebulosus. Histological section of skin from an infected bullhead $(\mathrm{a}, \mathrm{c})$ haemorrhage in the dermis and disruption of the melanophores in the pigment layer; $(\mathrm{b}, \mathrm{c})$ phagocytes (arrows) containing bacteria. (a,b) H\&E staining. (c) Gram stain

Additionally, this organism was not motile in solid agar matrices (i.e. TSI) and was only weakly motile in semisolid substrates (i.e. O/F basal medium). Gas was only produced in the fructose O/F test (Table 1). Serologically, the isolate was identified as E. ictaluri based on positive antibody staining (data not shown).
Table 1. Biochemical and carbohydrate characteristics of the case isolate compared to those described by Waltman et al. (1986). Results in parentheses are different than those reported for Edwardsiella ictaluri. NR: not reported

\begin{tabular}{|lcc|}
\hline Characteristic or & Case isolate & E. ictaluri \\
substrate tested & & \\
\hline Gram stain & - & - \\
$3 \%$ KOH & + & NR \\
Catalase & + & + \\
Cytochrome oxidase & - & - \\
Indole & - & - \\
Simmon's citrate & - & - \\
Triple sugar iron & K/A & K/A \\
Arginine & - & - \\
Lysine & + & + \\
Ornithine & + & + \\
Nitrate & + & + \\
Methyl red & $(-)$ & + \\
Vogues-Proskauer & - & - \\
Gelatin & - & - \\
Phenylalanine deaminase & - & - \\
Galactose & + & + \\
Fructose & + & + \\
Lactose & - & - \\
Maltose & + & + \\
Malonate & - & - \\
Mannose & + & + \\
Rhamnose & - & - \\
Sorbitol & - & - \\
Sucrose & - & - \\
Trehalose & - & - \\
Xylose & - & - \\
Motility & - & - \\
H.SO ${ }_{2}$ production & & - \\
\hline & - & - \\
\hline
\end{tabular}

\section{DISCUSSION}

While Edwardsiella ictaluri has been isolated from ictalurid species other than channel catfish, it is not a significant pathogen in all members of this family. For instance, while blue catfish are susceptible to this pathogen, they have also been shown to be less susceptible than channel catfish during experimental infections (Baoprasertkul et al. 2004). Brown bullhead exhibit different physiological responses to oxidative stress and exposure to some contaminants than channel catfish, so it is likely that they are uniquely susceptible to different pathogens (Hasspieler et al. 1994). $E$. ictaluri has been isolated from brown bullheads according to the AFS Blue Book (Shotts \& Plumb 2003); however, the circumstances in which this pathogen has been isolated are unknown. Few catfish species are commonly cultured; therefore, surveillance of other catfishes for disease is low. For this reason the significance of this pathogen in other ictalurid species including the brown bullhead is unknown. Likewise, the distribution of carrier fish in the wild is also unknown. This case report illustrates that E. ictaluri 
should be regarded as a pathogen of concern in tankcultured brown bullheads.

In many respects the disease resulting from $E d$ wardsiella ictaluri in brown bullheads is very similar to that observed in channel catfish, but there are several histological differences. While the multifocal, granulomatous inflammation and necrosis in the liver is consistent with the histopathology associated with ESC in channel catfish, the presence of lymphocytes at these sites of granulomatous inflammation is generally not observed in channel catfish. The pathological descriptions of splenic lesions in channel catfish include a depletion of erythrocytes (Blazer et al. 1985). The red pulp did not seem to be affected in brown bullheads. There was, however, an evident depletion of the lymphocytes (white pulp) in the spleen. Renal lesions are not generally observed in channel catfish, although they have been reported by Newton et al. (1989) in catfish with severe necrotizing hepatitis following E. ictaluri bath challenge. All of the brown bullheads from the present case exhibited generally severe renal damage. The pathological changes in the kidney were more like those described in association with E. ictaluri infection in Chinook salmon (Baxa et al. 1990).

The bullheads discussed in this case report were not intentionally infected with Edwardsiella ictaluri nor were they cultured in tanks or at a facility previously used for E. ictaluri challenges. These fish were captured from the wild prior to tank rearing. It is therefore probable that the fish were already covertly infected with the pathogen when captured, and that the disease was the result of the transport and temperature stress events. Interestingly, brown bullhead that were captured from the same creek during the spring of 2004 and then transferred to culture tanks in our facility also died with similar clinical signs. While pure cultures of bacteria were isolated from these fish, the bacteria were only identified as a short, gram-negative, OTCsusceptible rods. It is likely that organism was also E. ictaluri.

It appears that Edwardsiella ictaluri may exist in a carrier state in wild brown bullheads as has been suggested in channel catfish (Winton 2002). Since commercial sources of bullheads for laboratory tank studies are not available, precautions should be taken to prevent potential E. ictaluri outbreaks from wildcaught bullheads intended for laboratory research. Simple precautions that include good aquaculture management practice may circumvent such outbreaks of infected fish. For instance minimizing stocking densities, avoiding water-reuse when possible, and utilization of water temperatures that favor the host are strongly encouraged. Prophylactic treatment with antibiotics may help avoid an outbreak, but irresponsible antibiotic treatment is strongly discouraged by the authors. Chemotherapeutant application may also negatively impact normal fish physiology thus adding a confounding variable to the intended laboratory studies. In short, practices that minimize undue stress to wild-caught individuals are recommended given that specific pathogen-free animals are not available for laboratory research.

Acknowledgements. The authors thank B. Martin and the Pamlico Aquaculture Field Lab staff for collecting and holding brown bullheads for our stock population. We also thank C. Starliper at the National Fish Health Research Laboratory (NFHRL) for supplying reagents for bacterial identification and A. E. Goodwin for supplying antibody for serological identification.

\section{LITERATURE CITED}

Arcand-Hoy LD, Metcalfe CD (1999) Biomarkers of exposure of brown bullheads (Ameiurus nebulosus) to contaminants in the lower Great Lakes, North America. Environ Toxicol Chem 18:740-749

Arcand-Hoy LD, Metcalfe CD (2000) Hepatic micronuclei in brown bullheads (Ameiurus nebulosus) as a biomarker for exposure to genotoxic chemicals. J Great Lakes Res 26: 408-415

Baoprasertkul P, Peatman E, Chen L, He C, Kucuktas H, Li P, Simmons M, Liu Z (2004) Sequence analysis and expression of a CXC chemokine in resistant and susceptible catfish after infection of Edwardsiella ictaluri. Dev Comp Immunol 28:769-780

Baxa DV, Groff JM, Wishkovsky A, Hedrick RP (1990) Susceptibility of nonictalurid fishes to experimental infection with Edwardsiella ictaluri. Dis Aquat Org 8:113-117

Blazer VS, Shotts EB, Waltman WD (1985) Pathology associated with Edwardsiella ictaluri in catfish, Ictalurus punctatus Rafinesque, and Danio devario (Hamilton-Buchanan, 1822). J Fish Biol 27:167-175

Chung HY, Kou GH (1987) Edwardsiella ictaluri isolated from cultured eel in Taiwan. COA Fish Ser 1:125-126

Crumlish M, Dung TT, Turnbull JF, Ngoc NTN, Ferguson HW (2002) Identification of Edwardsiella ictaluri from diseased freshwater catfish, Pangasius hypophthalmus (Sauvage), cultured in the Mekong Delta, Vietnam. J Fish Dis 25: 733-749

Earlix D J, Plumb JA, Rogers WA (1996) Isolation of Edwardsiella ictaluri from channel catfish by tissue homogenization, filtration and enzyme linked immunosorbant assay. Dis Aquat Org 27:19-24

Hasspieler BM, Behar JV, Carlson DB, Watson DE, Di Giulio RT (1994) Susceptibility of channel catfish (Ictalurus punctatus) and brown bullhead (Ameiurus nebulosus) to oxidative stress: a comparative study. Aquat Toxicol 28:53-64

Hawke JP (1979) A bacterium associated with the disease of pond cultured channel catfish, Ictalurus punctatus. J Fish Res Board Can 36:1508-1512

Hawke JP, McWhorter AC, Steigerwalt AG, Brenner DJ (1981) Edwardsiella ictaluri sp. nov., the causative agent of enteric septicaemia of catfish. Int J Syst Bacteriol 31: $396-400$

Henson KL, Stauffer G, Gallagher EP (2001) Induction of glutathione S-transferase activity and protein expression in brown bullhead (Ameiurus nebulosus) liver by ethoxyquin. Toxicol Sci 62:54-60 
Johnston EP, Baumann PC (1989) Analysis of fish bile with HPLC-fluorescence to determine environmental exposure to benzo(a)pyrene. Environmental bioassay techniques and their application. Hydrobiologia 188-189:561-566

Kasornchandra J, Rogers WA, Plumb JA (1987) Edwardsiella ictaluri from walking catfish, Clarias batrachus L., in Thailand. J Fish Dis 10:137-138

Kent ML, Lyons JM (1982) Edwardsiella ictaluri in the green knife fish, Eigemannia virescens. Fish Health News 11: $1-2$

MacMillan J (1985) Infectious diseases. In: Tucker CS (ed) Channel catfish culture. Developments in Aquaculture and Fisheries Science, 15. Elsevier Science Publishers, New York, p 434-441

Mitchell AJ, Goodwin AE (1999) The isolation of Edwardsiella ictaluri with a limited tolerance for aerobic growth from channel catfish. J Aquat Anim Health 12:297-301

Newton JC, Wolfe LG, Grizzle JM, Plumb JA (1989) Pathology of experimental enteric septicaemia in channel catfish, Ictalurus punctatus (Rafinesque), following immersion-exposure to Edwardsiella ictaluri. J Fish Dis 12:335-347

Ploch SA, King LC, Kohan MJ, Di Giulio RT (1998) Comparative in vitro and in vivo benzo[a]pyrene-DNA adduct formation and its relationship to CYP1A in two

Editorial responsibility: David Bruno,

Aberdeen, UK species of ictalurid catfish. Toxicol Appl Pharmacol 149: 90-98

Ploch SA, Lee YP, MacLean E, Di Giulio RT (1999) Oxidative stress in liver of brown bullhead and channel catfish following exposure to tert-butyl hydroperoxide. Aquat Toxicol 46:231-240

Plumb JA, Sanchez DJ (1983) Susceptibility of five species of fish to Edwardsiella ictaluri. J Fish Dis 6:261-266

Shotts EB, Plumb, JA (2003) Enteric septicemia. In: AFS-FHS (American Fisheries Society-Fish Health Section) (ed) FHS blue book: suggested procedures for the detection and identification of certain finfish and shellfish pathogens, 2004 edn. AFS-FHS, Bethesda, MD

Waltman WD, Shotts EB, Blazer VS (1985) Recovery of Edwardsiella ictaluri from danio (Danio devario). Aquaculture 46:63-66

Waltman WD, Shotts EB, Hsu TC (1986) Biochemical characteristics of Edwardsiella ictaluri. Appl Environ Microbiol 51:101-104

Winton JP (2002) Fish health management. In: Wedemeyer GA (ed) Fish hatchery management, 2nd edn. American Fisheries Society, Bethesda, MD, p 559-639

Yuasa K, Kholidin EB, Panigoro N, Hatai K (2003) First isolation of Edwardsiella ictaluri from cultured striped catfish Pangasius hypophthalmus in Indonesia. Fish Pathol 38:181-184

Submitted: October 27, 2005; Accepted: February 10, 2006 Proofs received from author(s): June 1, 2006 